\title{
Tren Baru Homeschooling Islam di Indonesia Era Pandemi
}

\author{
Rantikasari \\ (Universitas Ibn Khaldun, Indonesi)
}

\begin{abstract}
Receive: 15/08/2020
Accepted: 09/09/2020

Published: 16/10/2020
\end{abstract}

\begin{abstract}
Abstrak
Konsep Pendidikan saatinimulairamaidiperbincankan. Takhanyakonsep Pendidikan formal yang menjadi pilihan banyak oran tua, tetapi juga ada sistem Pendidikan non formal dan informal. Homeschooling yang lebih dikenal sebagai sekolah rumah atau sekolah berbasis keluarga mulai menjadi trend baru dalam kancah Pendidikan. Model Pendidikan alternatif yang memiliki basis keluarga mulai banyak diminati dan sangat menari kuntuk diamati. Hadirnya beberapa homes chooling pada beberapa tahun terakhir yang mengindentifikasi dirinya sebagai Islamic homeschooling atau homes chooling yang menerapkan konsep dari Pendidikan Islam. Hasil temuan bahwa model Pendidikan yang didirikan oleh aktivis muslim universitas menunjukkan bahwa ada beberapa hal yang menjadi faktor dan alasan terkait dibentuknya homeschooling group khoiru ummah Bogor, diantaranya: (1) alasan ideologi, (2) alasan ketahanan keluarga, (3) alasan akademis, dan (4) alasan sosialisasi.
\end{abstract}

Kata kunci: Homeschooling Islam, Aktivis Muslim, Tren Pendidikan Islam, Era Pandemi

\section{PENDAHULUAN}

Perubahan pada minat sekolah dalam dunia Pendidikan di Indonesia yang terjadi pada saat memasuki abad ke-21 menjadi awal munculnya sekolah rumah atu yng saat ini dikenal dengan nama homeschooling (Loy Kyo, 2012: 17). Model Pendidikan di Indonesia selalu mengalami perubahan tiap waktuny. Sebelumnya hanya ada tiga model Pendidikan yang dikenal di Indonesia, yakni: model Pendidikan pesantren, model Pendidikan madrasah dan model Pendidikan sekolah (Steenbrink, 1996). Awal mula homeschooling adalah sebuah pernyataan dari Amerika pada tahun 1970an atas ketidak percayaan orangtua saat itu terhadap gagalnya Pendidikan yang dilakukn oleh sekolah formal yang saat itu menjadi primadona Pendidikan nomor satu. Ketidak percayaan orangtua atas
Pendidikan formal setidaknya mengaju pada dua hal, yakni yakni moral dan religiositas. Hal ini terjadi karena hasil sebuah penelitian bahw Sebagian besar anak-anak di Amerika yang lebih memilih homeschooling memiliki salah satu orangtua yang tidak melakukan pekerjaan di luar rumah (Bielick, et al: 2001, 8), tak hanya di Amerika, hal ini juga terjadi di belahan negara lain yakni: Kanada (Van Pelt, 2003: 33). Tidak hanya itu, faktor lain yang mengikutinya adalah Sebagian besar anak-anak di Amerika yang sekolah di homeschooling adalah berasal dari keluarga yang memiliki lebih dari tiga anak. (Basham, Merrifield, dan Hepburn, 2007: 12). Lisa Bergstrom (2012) mengatakan bahwa saat di perguruan tinggi, dimana saat dituntutnya kematangan pola diri, maka menurutnya anak-anak yang homeschooling 
akan mampu lebih baik dalam kinerja belajarnya.

Hal yang lain juga yang dibawa oleh Gerakan misionris ke Indonesia melalui gerakan misionaris Kristen selama kurang dari 25 bertahun yang lalu. Saat itu banyak kesulitan yang dialami oleh keluarga Kristen, salah satunya adalah adaptasi dalam berbahasa dan waktu lamanya untuk tinggal di Indonesia. Dua kesulitan inilh yang juga menjadi alasan mengapa akhirnya memilih homeschooling sebagai model Pendidikan untuk anak-anak mereka. Dan hal inilah juga yng ikut serta mempengaruhi para keluarga lain di Indonesia untuk sama mengikuti langkh tersebut (Loy Kyo, 2012: 14). Meski begitu alasan sebenarnya berkembangnya homeschooling di Indonesia amat sangat berbeda dengan alasannya berkembangnya model Pendidikan homeschooling di Amerika Serikat. Hadirnya model Pendidikan rumah atau yang dikenal dengn homeschooling terutama yang memiliki basis Pendidikan Islam di Indonesia adalah sebuah jawaban yang bermula dari kegamangan dan harapan besar bagi para aktivis muslim di Indonesia atas tidak tercapainya tujuan Pendidikan Islam yang telah lebih dulu terjadi di pesantren, madrasah atau sekolah-sekolah yang mengatasnamakan diri sebagai sekolah yang berbasis Islam. Oleh karena itu, didirikannya homeschooling oleh aktivis muslim di Indonesia diharapkan mampu menjadi solusi alternatif yang ditawarkan, terlebih pada kondisi saat ini. dimana Pendidikan dikembalikan ke rumah masingmasing akibat pandemi yang terjadi di Indonesia khususnya dan seluruh dunia pada umumnya. Bukan hanya itu, alasan globalisasi juga ikut menjadi pengaruh mengapa aktivis muslim di Indonesia mendirikan sebuah homeshooling yang berbasis Pendidikan Islam, salah satu alasannya juga adalah globalisasi yang dianggap sebagai pemicu penyerangan nilai-nilai Islam dengan menggunakan sekulerisasi atau sekulerisme (al-Attas, 1981: 20-23) hal ini juga turut menyemarakkan Islamisasi Pendidikan, dan ini tentu tidak terlepas dari peran aktivis muslim universitas yang bergabung dengan institusi dakwah perguruan tinggi dari beberapa gabungan dari para aktivis muslim di berbagai perguruan yang memiliki satu tujuan dan harapan yang sama, ykni membenahi kondisi Pendidikan di Indonesia. Para aktivis muslim ini berakar dari universitas negeri di Indonesia yang didukung oleh mahasiswa dan professional di kota-kota di Indonesia. (Claudina Nef, 2015: 186).

Model pendidikan yang masih jauh dalam mewujudkan tujuan dan kekecewaan serta kegelisahan merosotnya karakter siswa akibat dari dampak buruk globalisasi inilah menjadi alasan terkuat para aktivis muslim tersebut untuk mendirikan sebuah Lembaga Pendidikan informal yang berbasis keluarga dan nilainilai keislaman mendirikan homeschooling group khoiru ummah. Yakni sebuah representative Pendidikan berbasis aqidah Islam yang bertujuan melahirkan generasi penghafal quran dan pemimpin masa depan.

Untuk itu tulisan ini dibuat guna untuk menganlisis secara mendalm tentng model Pendidikan homeschooling yang berbasis Islam juga menjabarkan tentang homeschooling yang didirikan oleh aktivis muslim yang didirikan untuk mengisi kekosongan pada peran yang dimainkan oleh pemerintah sebagai Lembaga yang paling berwenang menjaga dan bertanggung jawab terhadap karakter generasi.

\section{METODE PENELITIAN}

Tulisan ini akan menggunakan metode penelitian kualitatif, yakni penelitiannya dilakukan pada kondisi yang alamiah (natural setting). Alasan menggunakan metode ini adalah peneliti bermaksud mendapatkan pemahaman secara lebih mendalam proses Pendidikan Islam Homeschooling sebagai tren baru Pendidikan Islam. Tulisan ini akan mengelaborasi mengenai trend baru 
tersebut. Bahasan dikaji secara kepustakaan (library research). Dan analisis dilakukan melalui tiga tahap, yaitu reduksi data, penyajian data, dan penarikan kesimpulan.

Sumber data dalam penelitian ini adalah data primer yang diambil dari berbgai sumber pustaka terkait model Pendidikan homeschooling Islam, dari mulai sejarah kemunculannya dan alasanalasan mengapa mulai diminati di masyarakat. Serta menjadi paradigma model pendidikan alternatif yang menawarkan solusi atas kegagalan Pendidikan formal.

Setelah mendapatkan sumber data dalam penelitian, maka selanjutnya adalah dilakukan observasi data ke homeschooling group Khoiru Ummah Bogor yang mengatas namankan diri sebagai homeschooling yang menerapkan Pendidikan Islam. Dari mulai tujuan, nilainilai yang internalisasikan sampi dengan metode pembelajara dan proses pembelajara serta evaluasi penilaiannya.

Terakhir adalah menyimpulkan data dan observasi data dari penelitian ini yang telah diolah dengan metode kualitatif. Bahwa homsechooling group khoiru ummah mampu menjadi solusi lternatif untuk dunia Pendidikan Islam terlebih pada masa pandemi ini. msa Ketika Pendidikan Kembali ke rumah masing-masing, sehingg dalam konsep Pendidikan Islam telah mengembalikan peran orangtua sebagai pendidik pertama dan utama bagi anakanaknya.

\section{HASIL PENELITIAN}

Dalam Islam, yang paling
bertanggung jawab dalam proses
pendidakan anaknya adalah orangtua, yakni
ibu dan bapaknya. Setidaknya ada dua
alasan mengapa Islam memberikan
tanggung jawaban Pendidikan kepada
orangtua. Pertama dilihat bahwa secara
fitrah bahwa orangtua ditakdirkan oleh
Allah untuk menjadi orangtua bagi
anaknya. Karena itu secara kodratnya
orangtua adalah orangtua bagi anaknya. Dia

yang Allah takdirkan atas amanah tersebut, sehingga kelak dialah yang paling berhak untuk memberikan pertanggung jawaban tersebut kepada anaknya. Kedua bahwa sebagai orang yang diberikan amanah pertanggung jawaban kepada anak maka sudah pasti orangtua diberikan peran dan fungsinya, dimana salah satu peran dan fungsinya sebagai orangtua yakni memberikan Pendidikan untuk ankanaknya. Fungsi orang tua sebagai pendidik yang pertama dan utama terhadap anakanaknya, seringkali tidak memiliki waktu yang leluasa dalam mendidik anakanaknya. Selain karena kesibukan kerja, tingkat efektivitas dan efisiensi pendidikan tidak akan baik jika pendidikan hanya dikelola secara alamiah. Dalam konteks ini, anak lazimnya dimasukkan ke dalam lembaga sekolah. Ketika anak telah masuk bangku sekolah, orang tua hendaknya menyekolahkan di tempat yang mewakili visi dan misi yang sama dengan nilai-nilai atau keyakinan yang diajarkan di rumah. Sekolah yang dipilih hendaknya mampu mewakili orang tua untuk mendidik anak dalam mengembangkan potensi-potensi yang dimilikinya. Oleh karena itu, definisi pendidik pada titik seringkali hanya disematkan kepada mereka yang memberikan pelajaran peserta didik atau yang memegang suatu mata pelajaran tertentu di sekolah. Berawal dari pemahaman inilah akhirnya seringkali orang tua melepaskan peran dan tanggung jawabnya sebagai pendidik bagi anakanaknya.

Landasan filosofi inilah yang kemudian perlu untuk menjadi rujukan dalam pemahaman mendidik anak. Sehingga di masa apapun orangtuaa yang hakikatnya sebagai Pendidik pertama dan utama tersebut memiliki tanggung jawab besar dalam mendidik anak, membersamai anak menjadi anak yang sholih dan sholihah, sehingga kelak mampu mempertanggung jawaban amanahnya kepada Allah Swt. Orangtua mampu mendidik anaknya pada masa apapun, baik masa sebelum pandemi ataupun masa 
pandemi. Sehingga kejenuhan dalam belajar daring di rumah tidak menjadi beban orangtua yang tentunya akan berpengaruh terhadap minat dan motivasi belajar anak. Hal ini yang terjadi di Homeschooling Group Khoiru Ummah Bogor pada masa pandemi ini. Dimana bobot pembelajaran dikurangi, meski memang bobot pembelajaran di homeschooling terbilang sangat kecil dibanding sekolah formal atau non formal lainnya. Hal itu dilakukan adalah untuk mengurangi kesulitan orangtua dalam membersamai anak pada proses pembelajaran daring, termasuk di dalamnya membersamai anak dalam mengerjakan tugas-tugas yang diberikan oleh sekolah. Meski secara hakekat homeschooling adalah model Pendidikan rumah yang mengedepankan tugas utama orangtua sebagai pendidik dan memposisikan sekolah hanya sebagai partner orangtua, ada saja orangtua yang lalai dan kesulitan Ketika mereka benarbenar dihadapkan pada posisi dimana mereka betul-betul dijadikan pendidik pertama dan utama tersebut. Ketidak siapan atau banyaknya tugas dan prioritas lain menjadikan tanggung jawab seolah adalah beban baru di era pandemic ini. oleh karennya mengkristalkan filosofi menjadi penting, agar tanggung jawab bukan sebatas beban tapi ibadah yang harus ditunaikan dengan hati ynag bahagia. sehingga Ketika aura kebahagiaan itu memancar dalam diri orangtua,hal itu akan ikut menyalurkan energi positif untuk anak dan menumbuhkan minat dan motivasi anak dalam menempuh proses pembelajaran dan Pendidikan karena orangtua dan anak samasama ingin mencapai tujuan dari Pendidikan itu sendiri. Maka Homeschooling Group Khoiru Ummah Bogor, memiliki sekiranya tiga tujuan yang menjadi alasan mengapa kemudian didirikan. Alasan utamanya adalah: (1) moral dan alasan agama dan (2) alasan kesatuan keluarga, juga beberapa alasan lain seperti (3) alasan akademis, dan (4) alasan sosialisasi (Asmani, 2012: 68-72).
Sekolah Dasar Homeschooling Grup Khoiru Ummah Bogor berdiri dilatar belakangi sebuah diskusi tentang konteks globalisasi yang lebih luas, hal ini membuat para aktivis muslim berfikir bahwa neoliberal sedang mencekeram tatanan dunia, hal ini ditentukan dengan banyaknya arah dan keputusan yang tidak sejalan sengan Islam. Baik dalam hal sosial, ekonomi, budaya dan politik. Perubahanperubahan ini membentuk transformasi struktural (Winarno, 2011: xiv) situasi semacamm ini kemdin yng mencorong para aktivis muslim untuk mendirikan homeschooling yang berbasil Islam. Posisi homeschooling berbsis Islam tersebut dalh jlan dn upya untuk Bersama meningglkn keterbelakangan serta keterbtasan muslim yang lin menuju Pendidikan yang lebih mulia, yakni Pendidikan Islam. Disampaikan Gnjar Wasisto bhwa pendirian homeschooling Islam adalah wujud dari rasa empati yang amat besar yang diberikan oleh aktivis muslim pergutuan tinggi seiring dengn semakin luasnya dampak buruk dari nilai-nilai sekulerisme, liberalisme dan kapitalisme yang menjdi nilainilai yang ada dalam perdaban Barat. Dari hal di atas yang menjadi latar belakang pendirin setidaknya ada beberapa peran serta homeschooling group khoiru ummah untuk genersi dan Pendidikan Islam, diantaranya: menyelamatkan generasi dari hancurnya pemikiran yang berujung pada kerusakan moral dan perilaku menyimpang. (2) Sebagai bentuk tanggung jawab dari aktivis muslim untuk mengopinikan Pendidikan Islam yang sesuai dengan Al Quran dan sunnah. (3) Bentuk kesadaran dan kepedulian aktivis muslim terhadap generasi muslim.

Dalam model Pendidikan homeschooling yang berbasis keluarga, maka tanggung jawab dalam proses Pendidikan anak menjadi tanggung jawab yang harus diemban oleh orangtua. Dalam Islam orangtua memiliki peran yang sangat vital dalam pendiidkan naknya, ykni sebgi pendidik pertma dan utama untuk anak- 
anaknya. Orangtua yang melahirkan anak, orangtua yang mengajarkan anak cara makan, cara berjalan dan cara berbicara. Sehingga orangtua juga yang memiliki tanggung jawab untuk mendidik anaknya menjadi anak yang shalih dan shalihah. Karena bagaimanapun anak adalah aset bagi orangtua dan merupakan investasi terbesar orangtua baik di dunia ataupun di akhirat. Anak yang shlih dan shalihah akan menjadi sumber kebahagiaan untuk orangtua di dunia dan menjadi perantara orangtua untuk masuk syurga di akhirat kelak. Oleh karena itu, mendidik anak menjadi shalih dan shalihah adalah tanggung jawab orangtua yang sudah tertanam sejak anak masih dalam kandungan. Hal ini menjadi peringat bahwa peran mendidik tidak bisa dialihkan kepada orang lain. Sehingga posisi guru di sekolah hanyalah partner orangtua dalam mendidik anak sesuai dengan tujuan Pendidikan dari sang pencipta anak, yakni Allah Swt.

Maka berdirinya homeschooling berbasis Islam ini memiliki dua sisi, yakni sisi untuk peserta didik dan sisi untuk orangtua. Sisi uuntuk peserta didik adalah dengan berdirinya homeschooling Islam ini diharpkn mmpu melhirkan anak-anak yng sholih dan sholihah yng memiliki akal yang cerdas dan jiwa yang sholih. Dengan menginternalisasi nilai-nilai Islam dalam proses pendidikannya dihrapkan akan lahir generasi pemimpin yang mulia yang dapat menyelamtkan generasi dan dunia ini. pada sisi orangtua adalah dengan berdirinya homeschooling yang berbasis Islam adalah mengembalikan fitrah orangtua sebagai pendidik ank-anaknya, menjadikan orangtua berperan aktif dalam proses Pendidikan anak, sehingga turut membantu lahirnya generasi shalih yang mulia untuk menciptakan peradaban yang mulia. Selain itu juga agar para orangtua yang belum memiliki ilmu yng cukup dalam mendiidk anak mengetahui dan memahami ilmu dalam mendidik anak, sehingga paham pola asuh untuk anaknya dengan tepat. Karena Homeschooling Group Khoiru Ummah tidak hanya mengajarkan ilmu kepada anak, juga mengajarkan ilmu mendidik kepada orangtua, hal ini dilakukan agar pendidikan yang diberikan di sekolah sejalan dengan pendidikan yang diberikan di rumah, jika hal itu terjadi, maka orangtua dan guru akan saling sinergi dalam mencetk anak-anak sesuai dengan output yang diharapkan. Sinergitas ini kemudian yang akan mampu menciptakan hormone kerja sama yang aktif antara orangtua di rumah dan guru di sekolah. Kesholihan anak dalam hal ini akan mampu memancar tidak hanya untuk dirinya sebagai individu atau untuk keluarganya akan tetapi untuk komunitas bahkan masyarakat. Karena Homeschooling Group Khoiru Ummah bertekad melahirkan generasi hafizh yng memiliki karkter pemimpin.

Selain itu, Homeschooling Group Khoiru Ummah juga memiliki sisi yang lain dalam hal menyelesikan masalah yang terjadi pada anak, tentu penyelesaian masalah yang dilakukan tidak akan pernah dapat dilakukan oleh sekolah formal. Adapun permasalahan itu adalah: (1) kasus untuk anak yang kesulitan dalam memahami pembelajara atau terlambat dalam menangkap pelajaran. (2) kasus untuk anak yang hiperaktif. (3) kasus untuk anak-anak yang kesulitan dalam bersosialisasi dengn lingkungannya. Kasuskasus ini tentu hanya bisa diselesaikan oleh Pendidikan berbasis rumah,

\section{Berkembangnya}

Islamic Homeschooling ini memang banyak diikuti oleh orang tua Muslim yang secara perekonomian telah mapan (kelompok ekonomi menengah ke atas). Hal demikian nampaknya membenarkan tesis yang dikemukakan oleh Michael R. J. Vatikiotis terkait kebangkitan kembali semangat keagamaan yang merupakan fenomena kelas menengah di wilayah-wilayah perkotaan (segmen masyarakat yang paling banyak tersentuh oleh pembangunan ekonomi dan perubahan sosial). Fenomena ini berpengaruh luas pada meningkatnya ketaatan beragama pada orang-orang Islam 
yang sedang menikmati kemakmuran sebagai kelas menengah.

Kecintaan kepada Islam dari kalangan "kelas menengah" Muslim yang tengah tumbuh (muslim rising middle class), nampaknya seperti menemukan jawaban dari kegalauannya terkait efek negatif dari globalisasi pada eksistensi sekolah-sekolah Islam yang salah satunya adalah homeschooling. Kelompok ini berusaha untuk mendapatkan pendidikan Islam yang berkualitas bagi anak-anak mereka, dimana peserta didik tidak hanya bergumul dengan ilmu-ilmu yang penting untuk kehidupan masa kini di dunia, namun juga ilmu-ilmu dan amal Islam.

Sintesa supply and demand yang demikian inilah nampaknya yang mendukung sekolah-sekolah Islam cepat sekali berkembang. Sintesa demikian berkembang dalam kerangka masyarakat yang digempur oleh perubahan sosial sehingga manusia membutuhkan agama sebagai tempat untuk kembali. Sebagai akibat dari hal ini, masyarakat kembali pada ketaatan beragama (religious devotion) senada dengan tesis yang dikemukakan oleh Naisbitt. Vatikiotis menguatkan bahwa telah terjadi gejala dislokasi sosial yang luas dan menghinggapi masyarakat yang sedang berubah cepat. Banyak orang kemudian kembali pada agamanya untuk memperteguh diri sebagai reaksi atas hancurnya tatanan nilai-nilai moral sosial tradisional yang terjadi di sekitar mereka.

Setidaknya terdapat dua alasan yang menjadikan fenomena berdirinya Islamic Homeschooling yang salah satunya adalah Homeschooling Group Khoiru Ummah menjadi strategis di mata masyarakat secara umum. Pertama adalah terbentuknya pola baru dalam santrinisasi yang sejatinya juga terjadi dalam konteks sekolah-sekolah Islam elite lainnya. Pola santrinisasi ini setidaknya digambarkan dalam dua cara, (1) peserta didik dalam sekolahsekolah itu umumnya telah mengalami re-islamisasi. Hal ini karena disamping mempelajarai ilmu-ilmu umum, mereka juga mempelajari ilmu-ilmu Islam dengan proses penanaman ajaran dan praktik-praktik Islam yang lebih intens bila dilakukan dengan sistem asrama. (2) Peserta didik selanjutnya membawa Islam yang telah mereka pelajari dari sekolah ke rumah, dalam banyak kasus bahkan mereka mengajarkan kepada orang tua yang acapkali mengetahui lebih sedikit tentang Islam. Akibatnya agar tidak mengecewakan sang anak, mereka mulai mengundang guru privat untuk mengajarkan mereka tentang Islam.

Pada kasus Homeschooling Group Khoiru Ummah, orang tua yang akan menyekolahkan putra/putrinya diwajibkan untuk mengikuti diklat orang tua yang bertujuan agar orang tua menguasai konsep pendidikan anak berdasarkan Islam serta memiliki kompetensi untuk mendidik anak sehingga ada kesinambungan pemahaman antara pendidikan anak di sekolah dan di rumah. Selain diklat pada awal penerimaan siswa baru, orang tua diwajibkan mengikuti parenting secara berkala. Dalam konteks ini, orang tua diposisikan sebagai guru pertama dan utama bagi anak-anaknya. Sekolah bahkan secara langsung memberikan bekal ilmu, bimbingan, dan arahan kepada orang tua untuk menjadi guru bagi anak-anaknya. Pembinaan orang tua yang dilaksanakan oleh homeschooling ini sejatinya karena sedari kemunculannya, homeschooling memang menempatkan orang tua sebagai pendidik bagi anakanaknya.

Kedua, fenomena Islamisasi sistem dalam homeschooling. Hal tersebut karena model pendidikan homeschooling adalah sistem yang muncul pertama kali di Amerika, dengan muatan pendidikan yang berkembang di tengah masyarakat relijius berbasis dan cara pandang Kristen (Christian view of The World). Kemunculan sekolah-sekolah rumah di dekade 1970-an di Amerika sebenarnya juga lahir karena ketidakpercayaan orang tua terhadap pendidikan yang dilaksanakan di sekolah formal, minimal dalam dua hal yaitu standar moral dan relijiusitas. Gerakan yang sama juga terekspor ke Indonesia melalui 
para misionaris Kristen, kurang dari 25 tahun yang lalu. Kesulitan bahasa dan adaptasi yang dialami para keluarga misionaris ini, serta kemungkinan singkatnya waktu yang mereka lalui di Indonesia, mendorong mereka untuk menerapkan homeschooling bagi anak-anak mereka. Hal ini mempengaruhi beberapa orang di Indonesia untuk mengikuti jejak mereka. Sekalipun diikuti oleh sebagian kalangan di Indonesia, namun latar belakang hadirnya model sekolah rumah di Indonesia sedikit berbeda dengan alasan yang melatarbelakangi munculnya sekolah rumah di Amerika Serikat. Terlebih dalam Islamic Homeschooling, Islam menjadi landasan dasar dalam pengembangan kurikulum dan sistem pembelajarannya.

Homeschooling Group Khoiru Ummah dapat menjadi sebuah lembaga pendidikan yang berkembang di Indonesia. Salah satu aspek yang mempengaruhi perkembangan lembaga pendidikan ini adalah perkembangan kelas menengah muslim di Indonesia secara umum. Kalangan kelas menengah muslim inilah yang menjadi segmen bagi berkembangnya Homeschooling Group Khoiru Ummah sebagai sebuah lembaga pendidikan. Alasan praktis untuk menjelaskan keterhubungan fenomena ini adalah : pertama, perkembangan kegiatan keagamaan di wilayah perkotaan secara umum, tidak bisa dilepaskan dari alasan-alasan bahwa manusia membutuhkan agama sebagai tempat untuk kembali sebagai akibat kemajuan peradaban yang jauh dari nilainilai agama dan gempuran perubahan sosial begitu pesatnya terjadi di perkotaan. Berawal dari kembalinya masyarakat pada ketaatan beragama inilah akhirnya dibutuhkan lembaga pendidikan keagamaan yang terintegrasi dengan modernitas, sehingga dapat diterima masyarakat urban. Gejala ini sebenarnya merupakan bentuk dari dari rekonstruksi baru mengenai makna Ketuhanan di tengah modernitas. Naisbiit dalam sebuah bukunya yang berjudul High Tech, High Touch: Technology and Our Search for Meaning (New York: Broadway,
1999)., yang dikutip oleh Wasisto menyebutkan bahwa kemajuan teknologi yang berkembang telah membuat manusia modern menjadi gamang. Dalam konteks inilah, lahir sekolah-sekolah Islam elite seperti jejaring lembaga pendidikan Homeschooling Group Khoiru Ummah.

Kedua, secara ekonomis, untuk bisa mengikuti pembelajaran di sekolahsekolah elit tersebut membutuhkan dana yang tidak sedikit. Dalam kasus Homeschooling Group Khoiru Ummah yang secara kurikulum- siswa diwajibkan untuk dapat mengikuti kegiatan outing yang dilakukan tiap semesternya dengan cakupan yang berbeda-beda pada setiap jenjangnya. Semakin tinggi jenjang pendidikan, maka kegiatan outing yang dilakukan punya scope yang lebih luas. Pada jenjang SMA misalnya, siswa diwajibkan untuk bisa outing ke negara-negara di Asia. Pada jenjang SMP, siswa diwajibkan untuk bisa outing ke negara-negara Asia Tenggara. Hal ini juga berlaku untuk jenjang SD dan TK disesuaikan dengan pembelajaran yang telah ditetapkan sekolah. Kegiatan outing ini tidak lain bertujuan untuk menumbuhkan modal kultural berupa kemampuan kepemimpinan.

Ketiga, kebutuhan akan modal kultural untuk mendapatkan posisi sosial yang lebih baik di masyarakat. Berkembangnya sekolah-sekolah elit ini sebenarnya mengafirmasi pemikiran Bourdieu yang dikutip Moeflich Hasbullah yang menyatakan bahwa untuk meraih dan mempertahankan posisi kelas dalam masyarakat, masyarakat modern tidak lagi mewariskan modal-modal material pada anak-anak mereka melainkan membekalinya dengan 'cultural capital' (modal kultural) berupa lingkungan belajar (keahlian komputer, kursus-kursus dll), nilai-nilai pendidikan atau mengirim anakanak mereka ke sekolah-sekolah untuk mendapatkan posisi sosial yang lebih baik di masyarakat. Melalui transfer modal kultural ini, anak-anak modern akan memiliki sejumlah keistimewaankeistimewaan sosial sehingga 
dapat memasuki lingkaran-lingkaran elit masyarakat walaupun dengan absennya kekayaan individu.

$$
\text { Seperti yang terjadi, }
$$

perkembangan ekonomi masyarakat Muslim bertepatan dengan realitas sekolah Islam yang menawarkan pengajaran dan program pendidikan yang baik. Sekolahsekolah ini menyediakan keterampilan dan pengetahuan teknis yang memungkinkan kelas menengah yang muncul untuk memperkuat atau mempertahankan status sosial dan pekerjaan mereka. Hal ini merupakan salah satu alasan mengapa kemunculan sekolah Islam elit disambut oleh banyak orang tua Muslim, pembuat kebijakan/pejabat pemerintah, dan pendidik.

Berakar dari fenomena demikian inilah akhirnya sekolah-sekolah Islam elit (salah satunya Homeschooling Group Khoiru Ummah) tidak hanya mencukupkan diri pada pengembangan pemahaman keIslaman an sich, namun juga pengembangan pembelajaran sains, ditambah dengan kompetensi kepemimpinan yang terintegrasi dalam kurikulum pembelajarannya untuk membekali lulusannya terkait modal kultural yang sebelumnya telah dibahas berkelindan dengan fenomena kelas menengah muslim. Didasarkan pada alasan ini, tidak mengherankan jika anggota kelas menengah Indonesia (termasuk kaum Muslim), memilih untuk mengirim anakanak mereka ke sekolah umum dan swasta terkenal atau bahkan sekolah internasional untuk memberi mereka pendidikan yang unggul. Orang tua kelas menengah Muslim menginginkan agar anak-anak mereka terdidik dan memiliki pemahaman yang komprehensif bidang keIslam-an. Pada titik ini, kalangan ini menginginkan anak-anak mereka memperoleh keunggulan moral dan kebesaran karakter dengan berada dalam lingkungan intelektual yang menguntungkan. Berdasarkan pada pemahaman inilah, diharapkan akan terbentuk kebahagiaan dalam kehidupan mereka.

Dalam konteks penerjemahan, Sekolah Dasar Homeschooling Group Khoiru Ummah sebagai homeschooling dapat diartikan bahwa lembaga ini mempromosikan bentuk pendidikan informal. Pada saat yang sama posisi Sekolah Dasar Homeschooling Group Khoiru Ummah sebagai Komunitas Learning Center menempati posisi sebagai model pendidikan yang menekankan bentuk pendidikan non-formal. Bentuk pendidikan ini diartikan sebagai kegiatan pendidikan terorganisir yang diadakan di luar formal sistem pendidikan, secara mandiri, atau sebagai bagian penting dari sistem yang lebih luas, dengan tujuan memberikan layanan khusus kepada para peserta atau untuk membantu mengidentifikasi kebutuhan pembelajaran sehingga bisa cocok persyaratan dan mampu mencapai tujuan pembelajaran (Kamil, 2009: 11). Sedangkan Komunitas Belajar Pusat itu sendiri dapat diterjemahkan sebagai lembaga pendidikan yang lahir dari gagasan pentingnya posisi masyarakat dalam proses pengembangan pendidikan non-formal. Community Learning Center lahir dari tantang $\mathrm{n}$ yang dihadapi oleh masyarakat yang berputar seputar masalah kegiatan ekonomi dan pendidikan seperti meningkatnya jumlah orang yang rentan daya beli, kemiskinan, tingginya angka buta huruf, masalah dalam realisasi pendidikan dasar 9 tahun, angka putus sekolah yang tinggi, jumlah orang yang tidak bersekolah, pendidikan keterampilan yang dibutuhkan (hidup keterampilan) untuk orang dewasa, dan berbagai layanan pendidikan yang tidak dapat dilayani melalui pendidikan formal (Kamil, 2009: 82). Selain itu, ada juga kekhawatiran terkait dengan proses globalisasi yang melanda negara dunia ketiga termasuk internalisasi nilai-nilai yang seringkali tidak sesuai dengan cara memikirkan negara-negara dunia ketiga dan juga pemikiran Islam aktivis Islam di Indonesia (Wasisto, 20 Desember 2016). Menurut GW, konsep kelompok 
homeschooling dipilih karena beberapa alasan seperti: pertama, karena implementasi kurikulum yang lebih fleksibel yang dapat disesuaikan dengan perkembangan peserta didik. Dalam pola pendidikan di Sekolah Dasar Kelompok Homeschooling Khairu Ummah diterapkan kurikulum yang berbeda untuk peserta didik, setidaknya ada tiga tingkat pengembangan peserta didik yang tidak mengabaikan kompetensi dasar yang harus dimiliki oleh peserta didik. Untuk pelajar yang bisa mengikuti dengan pola pendidikan yang cepat, mereka memberikan materi pengajaran yang lebih cepat pada waktu-waktu tertentu oleh guru pendamping, seperti juga siswa yang mengikutinya media, atau standar. Dengan menggunakan pola seperti itu, siswa berkembang disesuai dengan kemampuan mereka untuk menerima bahan ajar dan tidak diperlakukan sama antara satu dan yang lain-lainnya. Contoh kegiatan yang digunakan dalam sistem ini adalah pembentukan kerangka Islam siswa pemikiran yang dilakukan dengan gaya klasik dan ditambah dengan pendekatan personal. Berdasarkan Perkembangan kepribadian dan cara berpikir Islami di sini, semoga anak-anak bisa berkembangkemampuan sendiri sesuai dengan minatnya (Wasisto, 20 Desember 2016 dan Junani, 18 Desember 2016).

Alasan kedua adalah karena pengelolaan kegiatan dan kebutuhan lain dapat dikelola bersama antara orang tua. Contoh kegiatan yang dapat dikompromikan bersama adalah olahraga kegiatan, kegiatan seni, kegiatan sosial yang sering dilakukan di ekstrakurikuler pada hari Jumat. Ada juga kegiatan keagamaan yang bisa dilakukan bersama setiap hari, seperti sholah (sholat) duha dan dhuhur. Selain itu, operasional pendidikan juga bisa dilakukan bersama. Meskipun demikian, yang utama Poin dari homeschooling adalah kehadiran orang tua dalam pendidikan anak-anak mereka. itu disajikan menggunakan pola kerja sesuai di rumah (Wasisto, 20 Desember 2016).
Berdasarkan terjemahan tersebut, Homeschooling Group Khoiru Ummah kemudian memantapkan dirinya sebagai model non-formal pendidikan dan informal sekaligus. Model pendidikan nonformal seperti dalam konteks Komunitas Learning Center, secara kelembagaan model pendidikan di luar pendidikan formal, informal seperti dikonteks pentingnya homeschooling sebagai upaya seumur hidup dalam pendidikan tinggi yang melibatkan keluarga dan lingkungan (Wasisto, 20 Desember 2016) Kurikulum Pendidikan Sekolah Dasar Homeschooling ini bertujuan untuk menentukan konsep umum kurikulum pendidikan di Grup Sekolah Dasar Homeschooling Khoiru Ummah. Dengan melihat desain umumnya kurikulum, diharapkan memperoleh gambaran umum tujuan yang ingin dicapai dalam Kelompok Sekolah Dasar Homeschooling Khoiru Ummah, guna terbentuknya kurikulum yang ideal yang mapu menghasilkan output yag ideal pula.

Kurikulum di Sekolah Dasar Homeschooling Group Khoiru Ummah memiliki tiga kompetensi, yakni kompetensi dasar, kompetensi inti dan kompetensi penunjang. Perbedaann dari ketga kompetensi ini adalah diantarnya: bobot pembelajaran, seperti jam pelajaran, dan juga perbedaan dalam sisi mata pelajaran. Masing-masing mata pelajaran ada yang masuk ke dalam kompetensi dasar, kompetensi inti dan juga ada yang masuk ke dalam kompetensi penunjang.

Dasar Kompetensi:

I. Tahfidhul Qur'an

I I. Bahasa Indonesia

III. Bahasa Arab

Inti Kompetensi

1. Tsaqofah Islam

2. Baca dan Tulis Qur'an

3. Tahsinul Qur'an,

4. Aqidah Islam,

5. Syariah (Ibadah Mahdloh, Akhlak, Mu'amalah),

6. Dakwah Islam,

7. Siroh Nabawiyah

8. Tarikh Islam. 
9. Mahfudzot

Kompetensi Penunjang

1. Sains

2. Matematika

3. Geografi

4. Ekstrakurikuler: olahraga, praktik sains, matematika, eksperimen geografi, kunjungan lapangan dan pelajaran Bahasa Inggris.

Kurikulum di Sekolah Dasar Homeschooling dirancang untuk menanamkan karakter Islam dengan model kurikulum terintegrasi. Model ini menekankan pada istilah "reposisi pembelajaran pengalaman ke dalam konteks yang bermakna "(Zubaidi, 2008: 264) atau dapat didefinisikan sebagai pengaturan integrasi berbagai mata pelajaran materi melalui tema lintas bidang studi untuk membentuk satu kesatuan yang utuh. Itu berarti bahwa batas antara bidang studi yang berbeda tidak ketat atau tidak ada (Wasisto, 20 Desember 2016). Semoga dengan menggunakan kurikulum ini, siswa dapat mempelajari nilai-nilai khuluqiyah (Nilai karakter Islam) tidak hanya pada pelajaran moral, tetapi juga pada mata pelajaran Islam lainnya, bahkan lainnya pelajaran umum.

Model kurikulum terpadu ini pada akhirnya membutuhkan pembentukan pembelajaran yang terintegrasi dengan fokus pada kegiatan kelas yang diselenggarakan dengan cara yang lebih terstruktur, mulai dari tema tertentu atau subjek tertentu sebagai titika pusatnya (inti pusat / pusat minat) suatu kurikulum. Secara tidak langsung, ini menjadi nilainya yang berbeda dari institusi homeschooling lainnya. Sekolah Dasar Kelompok Homeschooling Khoiru Ummah sebenarnya menekankan pada nilai tidak berwujud daripada nilai nyata. Keberhasilan dalam mempromosikan nilai tidak berwujud dapat dilihat dari kebermaknaan belajar itu dapat dilihat oleh para pemangku kepentingan, dalam hal ini adalah orang tua / wali siswa. Kelebihan ini kurikulum bisa terlihat dari perubahan signifikan pada peserta didik.
Pada saat yang sama, selain aspek kognitif dan psikomotorik, itu juga tertanam aspek kebajikan (aspek afektif) pada peserta didik (Yunani, 25 Desember 2016). Keberhasilan pendidikan lebih terbukti pada nilai-nilai tidak berwujud, karena Secara konseptual, kurikulum dirancang untuk mewujudkan pembentukan karakter Islami pada peserta didik.

Sehingga dengan apa yang telah dipaparkan di atas Homeschoolig Group Khoiru Ummah adalah upayanya mengintegralkan diri sebagai homeschooling Islam telah menanamkan konsep Pendidikan Islam dalam setiap elemen yang di dalam Lembaga pendidikannya. Baik dari segi kurikulum, materi ajar, proses pembelajaran sampai kepada evaluasi merupakan strategi yang dilakukan Homescholing Group Khoiru Ummah mengeksistensikan diri sebagai Lembaga Pendidikan Islam Informal. Kematangan dari sisi konsepsi Islam dalam nilai-nilai yang diterapkan di dalamnya setidaknya adalah bentuk solusi yang ditawarkan kepada para orangtua atas tantangan dunia Pendidikan hari ini. terlebih masa pandemi yang saat ini tengah terjadi. Meski secara proses pembelajarn dilakukan secara daring, akan tetapi nilai dn filosofi keislaman tetaplah tidak tergerus kondisi. Justru pengembalin peran Pendidikan kepada orangtua menjadi satu kesatuan yang memang saat ini terjadi dalam realitas kehidupan.

\section{KESIMPULAN}

Berdasarkan diskusi, hasil penelitian yang telah dilakukan terhadap Homeschooling Kelompok Khoiru Ummah Bogor dapat disimpulkan bahwa pendirian lembaga ini untuk beberapa orang alasan utama: (1) alasan moral dan agama, yang menjelaskan tentang keinginan Muslim yang tidak terpenuhi aktivis di Indonesia terhadap program pendidikan Islam yang ada di Indonesia, seperti pesantren, madrasah, dan sekolah, untuk membentuk 
pelajar yang ideal, serta masalah yang melanda negara-negara dunia ketiga juga efek globalisasi, (2) alasan kesatuan keluarga, yang menggambarkan harapan bahwa model pendidikan homeschooling dapat mengembalikan peran orang tua sebagai pendidik untuk anak-anak mereka, (3)alasan akademis, homeschooling diharapkan dapat membantu anak-anak dengan kesulitan belajar atau ketinggalan belajar karena masalah khusus tertentu pada siswa dan keluarga seperti siswa yang lambat belajar dan siswa yang hiperaktif dan (4) alasan sosialisasi, homeschooling diharapkan dapat memberikan solusi bagi siswa. masalah yang berkaitan dengan siswa yang sulit bersosialisasi dengan lingkungannya. Namun demikian alasan paling menonjol pendirian lembaga ini adalah karena alasan moral dan agama. Sehingga nilai-nilai yang dibawa dalam lembaa Pendidikan ini sanat sesuai denan kondisi yang tengah dihadapi. Sehingga strategi yang dilakukan dapat menjawa tantangan yang saat ini tengah dihadapi.

\section{DAFTAR PUSTAKA}

Al-Qur'an Tarjamah Tafsiriyah. 2013. Penerjemah: Muhammad Thalib, Yogyakarta: Ma'had An Nabawy.

Ar-Rasythah, Atha bin Khalil Abu. 2006. At-Taysir fi Ushul atTafsir: Suratul Baqarah, Beirut: Dar al Ummah, Cet. II

Azra, Azyumardi. 2012. Pendidikan Islam; Tradisi dan Modernisasi di Tantangan Tengah Milenium III,Jakarta: Grup Media Kencana Prenada.

Chandler, Bielick dan S.P. Broughman 2001. Homeschooling di Amerika Serikat: 1999 (NCES2001033). Washington, DC: Departemen Pendidikan AS, Pusat Nasional PendidikanStatistik. Tt
[5] Winarno, Budi. 2011. Globalisasi; Peluang atau Ancaman bagi Indonesia, Jakarta: Erlangga.

[6] Asmani, Jamal Ma'mur. 2012. Buku Pintar Homeschooling, Jakarta: FlashBooks.

[7] Bergstrom, Lisa. 2012. Apa Pengaruh Homeschooling terhadap Perkembangan dan Tes SosialSkor Siswa? Makalah yang Diserahkan dalam Pemenuhan Sebagian Persyaratan untuk MasterIlmu Pengetahuan di Universitas Pendidikan Wisconsin-Superior.

[8] Kho, Loy. 2012. Secangkir Kopi; Obrolan Seputar Homeschooling, Yogyakarta: Kanisius.

[9] Rahardjo, M. Dawam. 1999. Masyarakat Madani: Agama, Kelas Menengah, dan Perubahan Sosial.Jakarta: LP3ES.

Griffith, Mary. 2012. Buku Pegangan Tidak Bersekolah: Cara Menggunakan Seluruh Dunia Sebagai Anak AndaRuang kelas, diterjemahkan oleh Mutia Dharma, Home Schooling, Menjadikan Setiap Tempatsebagai Sarana Belajar. Bandung: Nuansa.

Kamil, $\quad$ Musthofa. 2009. Pendidikan Nonformal; Pengembangan Melalui Pusat Kegiatan BelajarMengajar (PKBM) di Indonesia (sebuah Pembelajaran dari Kominkan Jepang). Bandung:Alfabeta.

Nef, $\quad$ Claudia. 2015. Mempromosikan Kekhalifahan di Kampus; Debat dan Advokasi Hizbut TahrirAktivis Mahasiswa di Indonesia, dalam Madawi al-Rasheed, Carool Kersten, dan Marat Shterin(edt). Demistifikasi Kekhalifahan; Memori 
Historis dan Konteks Kontemporer. Oxford:Oxford University Press. dan Claudia R. Hepburn. 2007. Home Schooling: Dari Ekstrem keMainstrea. Edisi ke-2. Studi Dalam Kebijakan Pendidikan. Oktober 2007.

[14] Steenbrink, Karel A., 1996. Pesantren, Madrasah, Sekolah, Pendidikan Islam dalam Kurun Moderen. Jakarta: LP3ES.

Al-Attas, Syed Muhammad alNaquib. 1981. Islam dan Sekularisme, diterjemahkan oleh KarsidjoDjojosuwarno. Islam dan Sekularisme. Bandung: Penerbit Pustaka.

Van Pelt, Deani. 2003. Pendidikan Rumah di Kanada. London, ON: Pusat Kanada untuk RumahPendidikan.

Zubaedi. 2008. Desain Pendidikan Karakter; Konsepsi dan Aplikasinya dalam Lembaga Pendidikan.Jakarta: Kencana Prenada Media.

\section{Profil Penulis}

Penulis bernama Rantikasari, lahir di Bogor tanggal 26 Desember 1992. Pendidikan sarjananya di selesaikan di IAIN LaaRoiba tahun 2015 pada program studi Manajemen Pendidikan Islam dan saat ini sedang menempuh jenjang Pendidikan di pascasarjana Universitas Ibn Khaldun Bogor semester akhir pada program studi Magister Pendidikan Islam. Saat ini penulis beraktifitas sebagai guru sekaligus penulis. 